\title{
Social Relations at the Collective Level: The Meaning and Measurement of Collective Control in Research on the Psychosocial Work Environment
}

I Per Øystein Saksvik'

Professor, Department of Psychology, Norwegian University of Science and Technology, Norway

I Tove Helland Hammer

Professor, School of Industrial and Labor Relations, Cornell University, USA and Prof II, Department of Psychology, Norwegian University of Science and Technology, Norway

\section{Kjell Nytrø}

Psychologist, Centre for Work Management, Norway

\begin{abstract}
In this article, we suggest that organizational-level social relations should be defined and measured as workplace norms. We base this argument on new research on the components of the psychosocial work environment and on the availability of new techniques for measuring and analyzing workplace norms as organizational properties. Workplace norms emerge from interactions and negotiations among organizational actors, through which patterns of behavior, attitudes, and perspectives become defined as legitimate. This is an underestimated dimension of the psychosocial work environment that should be assessed with two types of data: self-reports by employees of their experiences in the workplace (task-level control) and self-reports by employees and employers of collective or group-level norms. Hierarchical linear modeling is an especially useful tool for analyzing the relationships between workplace norms and different organizational outcomes because it allows researchers to separate the effects of individual-level variables from group or organizational-level factors. Our approach is anchored in the Nordic perspective of the work environment developed over the past 50 years.
\end{abstract}

\section{KEY WORDS}

Social relations / collective control / workplace norms / measures of the psychosocial work environment / multilevel models

\section{Introduction}

he psychological and organizational conditions people experience in the workplace are often referred to as "the psychosocial work environment" (e.g., Hammer et al., 2004; Johnson \& Hall, 1994, 1996; Johnson \& Johansson, 1991; Kasl, 1998; Nieuwenhuijsen et al., 2010; Theorell \& Karasek, 1996). The impact of the psychosocial work environment on employees' health and well-being is increasing in research and practice due to the growing complexity of modern working life and because the physical work

\footnotetext{
$\overline{{ }^{1} \text { E-mail: per.saksvik@svt.ntnu.no }}$
} 
environment is no longer producing the large widespread negative health effects (e.g., asbestosis) that were observed around 1970. Despite years of theoretical and empirical work however, there is still no agreed upon conceptual definition of the construct, and as a consequence we have a large number of studies conducted with different theoretical models and measures. Our contribution in this article builds on the Nordic work environment tradition that stems from the 1950s and 1960s (Sørensen et al., 2012), but aspects of this tradition became a widespread theory internationally (and became extremely popular) with the job demands, control over work, and social support (JDC-S) model of Karasek and Theorell (1990) that historically built on limited parts of this Nordic tradition.

This may be the reason that the most commonly used definition of the psychosocial work environment, Karasek and Theorell's (1990) model of JDC-S, has been criticized for years as being underdetermined and in need of expansion. Suggested additions to the model have included individual characteristics, work process variables, and social and economic environmental factors (e.g., Kasl, 1998), the degree of fit between employees' skills, needs, and expectations and what the employer requires (Agervold, 1991), organizational culture (Skogstad \& Einarsen, 1996), and employees' opportunity for social mobility and a fair labor exchange (Siegrist, 1996). Empirical support for expanded definitions of the psychosocial work environment can be found in studies by, for example, De Jonge and Kompier (1997), de Rijk et al. (1998), Rennesund and Saksvik (2010), and van der Doef and Maes (1999). Further studies have tested models that emphasize organizational context factors, such as work group-level support from leaders (Bliese $\&$ Castro, 2000), the quality of the social environment (Bliese \& Britt, 2001), learning climate (Mikkelsen et al., 1998), and workplace norms (Hammer et al., 2004).

We are encouraged by research that has included work group- or organizationallevel context factors when examining the effects of the psychosocial work environment, but we find that the dimension we believe should be the core of the psychosocial work environment, workplace norms about social relations, has been underestimated for a long time and is rarely mentioned in new studies. In this article, we label this dimension "collective control," borrowing a term introduced by Gardell (1982), Aronson (1989), and Johnson (1989), to define the nature of social relations at the group, or organizational, level. Our conceptual definition of collective control differs from earlier use of the term, and we explain the difference in the next section. Our central purpose is to argue for a specific way to measure social relations at the collective level, which follows from our conceptual definition of the construct.

The article begins with our understanding of collective control, followed by a brief examination of how social relations have usually been assessed in research on the psychosocial environment, either by employing the original measure of social support developed by Karasek and his colleagues (1998) or by adaptations of their instrument. We then turn to the measures we believe will capture the collective, or context, nature of work group- or organizational-level social relations.

\section{Social relations at the collective level}

Based on concerns about the lack of attention to the social dimension of control in research on the health effects of workers' control over the labor process, Johnson (1989) used the term "collective control" to describe the combination of employee control 
over the work process and social relations in the workplace as a strategy for workforce survival. The importance of a collective response by workers to management control over the labor process as a way to resist exploitation and to reduce stress and physical ill health was a feature of both Scandinavian and American research from the 1960s onward (e.g., Aronson, 1989; Edwards, 1979; Gardell, 1982; Lysgaard, 1967; Montgomery, 1979). While social support was not the primary focus of the political analyses of worker control, the different mechanisms used by informal collectivities of workers (as opposed to formal structures of collective representation, such as trade unions) required forms of social support at the group or collective level. The interdependence of work process control and social support at both the individual and the collective level was seen as a collective coping system serving as protection against stress and cardiovascular disease (Johnson, 1989).

Our use of collective control does not include the labor process component. Our focus is on the nature of social relations at both the group (organizational) and the individual levels. We argue that the psychosocial work environment evolves from social and interpersonal relations between organizational actors. It is the result of formal and informal interactions and negotiations among employees, and between employees and management, through which patterns of behavior, attitudes, and perspectives become defined as legitimate. Over time, agreed upon activities and behaviors become routines, norms, and institutions that give organizational members a shared meaning or understanding of the workplace and their roles in it. Because a significant part of the psychosocial work environment is created through social interaction and interpersonal relations, it is a socially constructed phenomenon. This argument does not negate the importance of either individual differences in needs-values-motives and skills and abilities, or organizational characteristics like structure or technology as contributors to people's job performance, general health, and well-being at work. But, in our perspective, the emphasis in the psychosocial work environment is on social processes. Furthermore, while we do not consider it irrelevant how work is organized at the point of production (the labor process) or how power is distributed in the organization, we focus our analysis on the opportunities that job design and an organizational hierarchy create for the formation of work groups, the development of a workplace community, and the quality of workplace social relations. ${ }^{1}$ We argue that the collective dimension of the psychosocial work environment consists of the inter-related dimensions of workplace norms and relations between individuals in the workplace. Norms prescribe patterns of behavior, social relations, and rules about what is appropriate both at work and in the individual's relationship to his or her employer. ${ }^{2}$ They can be created, sustained, and changed by both management and employees. Where the leadership of an organization is powerful, its influence will be reflected in workplace norms covering a number of different activities, including work performance and other work-related behaviors. Where the workforce is powerful, the collective of employees will shape at least part of the norms that define workplace life. Both managers and workers join organizations where unwritten rules of conduct already exist, of course, and their behaviors are to some extent shaped by the norms they encounter. But, over time, they also redefine what is considered legitimate and create acceptance for new workplace behaviors and attitudes. In essence, the social actors as a collective both create the control of behaviors through the norms they develop and are controlled by the norms they create. 
In the organizational literature, norms are known mostly as a component of organizational culture, commonly defined as the essence, or core, of an organization, or as assumptions held by organization members about its reality. According to Schein (2010), an organizational culture consists of three layers going from what is observable and easily recognizable on the surface to what is hidden and difficult to put into words at the core. The first level consists of artifacts we can observe clearly. The intermediate level comprises beliefs and values, of which norms are a part. The innermost level of culture of the organization is a set of shared basic taken-for-granted assumptions about its nature and purpose. Basic assumptions are not necessarily in our conscious awareness-we may not be able to articulate them-but they lead to the behaviors we can observe and the values we can describe in words. This means that we are conscious of beliefs about what kinds of workplace behaviors are considered appropriate and expected (norms). In turn, this means that we can describe the norms, and they therefore can be measured. ${ }^{3}$ It is important for our argument in this article that workplace norms can be measured and modeled statistically.

"Social relations at the collective level" is an abstraction, in the sense that actual relations, both affective and behavioral, occur between individuals in one-on-one interactions or within groups. The link between the collective form of social relations (or collective control) and what happens at the individual level derives from research in cognitive psychology on self-concept (Kihlstrom \& Klein, 1994) and in social psychology on self-identity (e.g., Lord \& Brown, 2004). The self is a knowledge structure that helps organize and give meaning to memory. How people envision themselves, their selfconcept, is not one whole unit, but a confederation of selves that can emerge in different forms depending on time and context (Markus \& Wurf, 1987). Our self-concept can be separated into two levels, a personal and individual self, engaged in comparing ourselves to others to emphasize our own uniqueness, and a social self in which we define ourselves through our relations with others or through group membership. The social self can be partitioned into a relational self-identity, which is based on relations with specific others such as a coworker or a manager, and a collective self-identity, where we define ourselves in terms of our group memberships. The different versions of our self-identity will emerge to govern our cognitions, affect, and behaviors in response to contextual primes, such as company policies and practices, job design, reward systems, leadership styles, or organizational norms.

Both descriptive norms ("This company owns you, skin and all") and injunctive norms ("In our workplace, we expect people to help one another with personal problems") act to prime collective self-identities. The social self can alternate between a relational self-identity in interactions with a coworker who might need social support or with a manager who wants a task accomplished and a collective self-identity when expectations about everyone's behavior are made salient. The movement of the self from a "you and me" relationship to a "we or us" relationship is that part of our model which links the social support component of Theorell and Karasek's (1996) theory to social relations at the collective level. Both laboratory and field research has testified to the psychological and physical health benefits of the ties that create collective social responses at the group and organizational level, especially in depersonalized workplaces and communities (e.g., Lawler et al., 2009).

A parallel argument about the importance of including the collective level in research on organizational life can be found in the justice literature. Concerns about fair 
treatment occur at the relational level, in exchanges or interactions between individual actors, or between an actor and an agent of the employer, and concerns about a justice climate, which refers to how a group as a whole is treated. Fairness or unfairness is an individual experience; justice is a group- or organizational-level characteristic (Brewer \& Chen, 2007; Spell \& Arnold, 2007).

\section{The Demand-Control-Support model}

The most frequently used measure of the psychosocial work environment is the Job Content Questionnaire (JCQ; Karasek, 1985; Karasek et al., 1998), derived from the original job demand-decision latitude model (Karasek, 1979). Often we find that the psychosocial work environment is defined based on this model. Part of the logic behind the original demand-control model came from Karasek and Theorell's (1990) interest in explaining the relationship between learning and stress. They argued that job stress may inhibit learning because it leads to strain when working in a job with high demands over which the worker has low control. Job-induced learning may reduce stress, however, when the worker has some control over the manner in which the job is executed (decision latitude) through development of confidence and self-esteem. With control over the work process, job demands might be seen as challenges and opportunities for growth and learning rather than burdens.

Increased control over the work situation is often viewed as a critical variable in reducing the effect of demands on the risk of stress-related illness (Israel et al., 1989; Karasek, 1992; Landsbergis \& Vivona-Vaughan, 1995; Parkes \& Sparkes, 1998; Pierce \& Newstrom, 1983; Wahlstedt \& Edling, 1997). Most often, however, control is operationalized quite narrowly with the JCQ decision latitude scale, which has been criticized for being a mix of job control, skill variety, and job complexity (e.g., Frese, 1989; Ganster, 1989).

A number of critical reviews of the scale were published in the late 1990s when its popularity as an operational definition of the psychosocial work environment was obvious. Van der Doef and Maes (1999) showed that it was only those aspects of job control that correspond with the specific demands of a given job which moderated the impact of high demands on well-being. Other evaluations concluded that decision latitude as operationalized in the JCQ measures primarily measure task-level latitude (De Jonge \& Kompier, 1997) and is individual- and "here and now" oriented (Landsbergis et al., 2000). Swedish researchers found that a substantial part of the variation in strain variables utilized in the demand-control model was explained by the organizational level (Soderfeldt et al., 1997). The original JCQ questionnaire from 1985 did include scales for measuring organizational-level control and job insecurity, but the questionnaire was merely considered useful for microlevel job characteristic analytic purposes (Karasek et al., 1998, p. 323). We believe that this is a common feature in most of the attempts to operationalize the psychosocial work environment. Jones et al. (1998) suggested, based on another research review, that the success of the demand-control model in driving research led to a neglect of a range of other psychosocial factors, and that more complex psychosocial models which take into account the work context and the changing nature of work are needed, to which Sparks and Cooper (1999) added differences across occupations using job-specific models, and 
Johnson and Hall (1996) recommended inclusion of work-related social support and the gendered work process.

The demand-control model was augmented by including social interaction at work, labeled social support (Karasek \& Theorell, 1990). Within the domain of psychosocial factor research, one has traditionally focused on the relational component by narrowing it down to an issue of social support (e.g., House, 1981). Studies on cardiovascular disease and absenteeism have shown that social support is one of the most important factors that may reduce stress and strain, either directly or indirectly, in the workplace (Karasek \& Theorell, 1990; Shumaker \& Czajkowski, 1994). Karasek and Theorell (1990) also pointed out the potential negative consequences of working in social isolation or being prevented from coming into contact with other coworkers (so-called iso-strain).

During the past ten years, an increasing number of studies have applied multilevel modeling to explain individual variations in work-related stress and other healthrelated outcomes. One of the goals of this research was to investigate whether and how to operationalize the JDC-S model at the individual, the organizational, or both levels of analysis (De Jonge et al., 1999; Morrison et al., 2003; Soderfeldt et al., 1997; van Yperen \& Snijders, 2000). Another purpose was to investigate whether or not variables at the group or organizational level of analysis have a cross-level impact on dependent variables at a lower level, over and above the predicting stressors at the individual level (Bliese \& Britt, 2001; Bliese \& Castro, 2000; Hammer et al., 2004; Jex \& Bliese, 1999; Rennesund \& Saksvik, 2010; van Yperen \& Snijders, 2000).

Since 2000, multilevel analyses by way of Hierarchical Linear and Nonlinear Modeling (HLM) have used Karasek's concepts, especially in safety and psychosocial research. For example, Torp et al. (2005) showed how the use of personal protective equipment correlated positively with social and management support. Dollard and Karasek (2010) described how Karasek's (2008) “associationist” demand-controlstress disequilibrium theory can be used to build a psychosocial safety climate based on multilevel physiological responses on the social collective level. In an epidemiological study, Ilies et al. (2010) found that job control and organizational support had crosslevel moderating impacts on the relationships of workload with affective distress and blood pressure. These associations were weaker for participants who reported having more control on their job, as well as for participants who reported receiving more support.

Despite all the critical reviews and the increased use of multilevel modeling, the research literature still gives the impression that researchers assume the existence of a commonly understood definition of the psychosocial work environment. This definition includes, but is not necessarily limited to, the small number of work variables that have been identified as causes of cardiovascular heart disease. For example, the three JCQ scales, demands, control, and social support, became the central psychosocial variables in Swedish research on work-related causes of stress and cardiovascular disease (Karasek, 1979, 1997). However, what exists as descriptions of the psychosocial work environment can more aptly be viewed as lists of variables than conceptual definitions. The lists differ in scope and content across etiological studies. In European, particularly Scandinavian, research, psychosocial risk factors in the work environment have been dominant in causal models of stress and cardiovascular disease at the expense of individual difference variables, while in American studies of occupational health it has been the other way around, a phenomenon Kasl (1996) 
attributed to the relative importance European and American workers attach to their work experiences.

Because most of the work environment research has been dependent variable driven-its purpose has been to find predictors of disease-there may not have been much of a need for developing theoretical models that define what the psychosocial components really are. More recent research has tried to expand the definition of the psychosocial work environment however, by connecting it to other related concepts. A good discussion of several models of the psychosocial work environment is found in Kompier (2002). Hasle and Møller (2007) demonstrated how a culture based on conflicts and opposing interests was less beneficial than a culture based on mutual trust and respect due to the growth of social capital in the latter. Oksanen et al. (2008) found that increasing levels of individual social capital were associated with sustained good health.

Our intention is not to develop a comprehensive model of the psychosocial work environment that covers all aspects suggested in the literature. Instead we examine the one dimension we have found to be underestimated for a long time and inspired from the first Nordic work environment research-social relations at the collective level. We anchor this focus in the ongoing debate about higher-level control presented in the former discussion of the model of Karasek and Theorell (1990) and in the empirical efforts to uncover the variance in job stress and worker well-being attributable to group- and organizational-level factors. We defined the social relations dimension briefly in the introduction to this article. In the next section, we provide a more detailed analysis of the construct before we turn to its measurement.

\section{The social relations dimension of the psychosocial work environment}

From a series of studies of how employees perceive and appraise their work environment, James and his colleagues (James \& James, 1989; James \& McIntyre, 1996; James \& Sells, 1981) identified four latent factors: (1) role stress and lack of harmony, (2) leadership facilitation and support, (3) job challenge and autonomy, and (4) work group cooperation, friendliness, and warmth. ${ }^{3}$ All but the first of these factors are similar, but not identical, to the variables researchers have identified as components of the psychosocial environment (e.g., Emery \& Thorsrud, 1976; Gardell, 1971, 77; Karasek \& Theorell, 1990). The main difference lies in the importance of the work group, not only as an entity in the work organization but also as a dynamic and constructed community.

Most of the items used in measures of worker control assess formal participation and interaction and are directed toward the individual's own perceptions ("I have influence over the policies of the employee association"), but some are also directed at the collective experience ("My work group or unit makes decisions democratically"). The more informal aspects of control are not represented and may also be more difficult to assess. Some may be recognizable to both outside observers and insiders, such as the workplace norms and the informal organization with its friendships and communication networks. Others lie below the surface and may not be present in people's awareness, such as assumptions held by employees and management about the mission of the organization and organizational values, that is, the ideals, standards, and goals that operate to dictate what type of work should be done and how it should be carried out (Dyer, 1986). 


\section{Workplace norms as collective control}

Organizational or workplace norms are patterns of behaviors, social relations, and rules about what is appropriate, which are taken for granted and seen as legitimate by organization members (Katz \& Kahn, 1978). They are shared expectations about how things are done in the workplace, how employees should behave towards coworkers and managers, how managers should treat subordinates, how hard one should work, how one should treat information, who should interact with whom, and so on. Norms prescribe and sanction behavior. Organizational values-what organizational members consider desirable or worthwhile-serve to justify the norms and to provide employees with a basis for choosing one course of action over another or defending why one set of actions or thoughts is preferable to another.

The importance of tacit social norms in influencing work performance was demonstrated early in the history of social research in industry, going back to the Hawthorne studies (Rothlisberger \& Dickson, 1939). Later research on group processes and management decision making demonstrated how workplace norms influence productivity levels (e.g., Baron et al., 1992), absenteeism patterns (Hammer et al., 1981), and personal well-being (Argyris \& Schön, 1996). Research has also shown how stressful the workplace can be for new employees who unwittingly violate the implicit rules of conduct embedded in organizational norms (Cooper \& Payne, 1992), and for workers who are forced to choose among conflicting behavioral expectations (Hammer et al., 1991).

Hammer et al. (2004) showed how workplace norms might affect the individual level of job stress. They argued that most workplaces or organizations have some set of informal rules that govern any type of appropriate employee behavior. These expectations are shared understandings and agreed upon beliefs about the working conditions.

\section{Social relations at work}

Within the domain of psychosocial research, the relational component has usually been defined as an issue of social support, operationalized as the extent to which significant others, such as coworkers, supervisors, and friends, are able to alleviate personal or work-related problems. Winnubst and Schabracq (1996) refer to research showing that interaction with others, such as clients, supervisors, or coworkers, is a main component in the emergence of stress and strain, but in their review of the social dimension in organizations, they do not move beyond the well-researched empirical and theoretical paradigm of social support.

We suggest that the meaning of social and interpersonal relations in the workplace goes beyond the traditional definition of social support, however, in part because research has shown that the ability to be a part of friendship networks, collaborative alliances, and interest groups in the workplace affects people's psychological adjustment to both their jobs and the conditions of employment. Early research on alienation and withdrawal from work demonstrated that workplace social relations can go a long way to compensate for tiresome and repetitive tasks by giving people a positive reason for enduring tedious work (Blauner, 1964; Kahn, 1992). Lysgaard (1967) showed how development of shared attitudes and strong personal ties among industrial workers can serve as a defense against unwanted management strategies to control the workforce. 
Social relations at work have also been found to influence a person's development of self-concept and social identity outside the work arena. For many, work gives meaning to existence by allowing them to perform tasks in a social setting that is conducive to developing self-identity and personal integrity (Winnubst \& Schabracq, 1996).

By community we mean the opportunity employees have to establish friendship ties with coworkers, to communicate openly and freely with one another, and to work in an environment characterized by interpersonal trust, respect, and cooperation, free from interpersonal competition and conflict and racial or sexual harassment. Social support would be one aspect of a work environment that allowed and encouraged the building of a social community and we see the broader conception more linked to the collective control concept than related to social support.

Solidarity refers to the existence of shared attitudes about employees' duties and obligations to their coworkers based on a recognition that they constitute a common interest group as wage earners (Heckster, 1996). Solidarity serves first and foremost to protect employees against exploitation (real or imagined) or management breaches of commonly understood agreements about work performance, overtime requirements, absenteeism, etc. Solidarity also depends on open communication, trust, and respect among members of the workforce, but it has more political overtones than does the community component.

Hammer et al. (2009) examined the ways in which presidents of local teachers' unions were able to foster commitment toward, and a willingness to work for, the union among the members. They found that presidents who involved rank and file union members in decisions about the union's policy in wage negotiations, and took into account the members' preferences for specific wage patterns, had members who were more committed to work for the union, were more loyal to union, and did more active volunteer work to help the president administer the union. The presidents' ability to negotiate good wage outcomes, an example of distributive justice, was also related to the way the teachers felt about the union, but it was the leaders who gave members a voice in important decisions by consulting with them and listening to them who had both loyal members and volunteers willing to work. Part of this procedural justice effect may have been due to the "quid pro quo" of social exchange, but the more likely explanation lies in the message the leaders sent about the value of each member to the organization.

\section{Measuring the social and relational aspects of the psychosocial work environment}

An assessment of the psychosocial work environment should involve the collection of two types of data: the traditional descriptions by employees of their perceptions of the workplace that dominate most questionnaires today and the more seldom found descriptions of collective or group-level phenomena we have listed above. The questions asked of employees in some recent large-scale work environment surveys often do not differentiate between the individual subjective level and the collective level when assessing the social and relational aspects (e.g., The Generic Job Stress Questionnaire, National Institute of Occupational Safety and Health (NIOSH), 1998; QPS-Nordic, Lindström et al., 1997; The Second European Survey on Working Conditions, European Foundation, 1997; The Copenhagen Psychosocial Questionnaire (COPSOQ), Rugulies 
et al., 2010). This differentiation is important because the psychological meaning of responses to individual- and collective-level questions is different, that is, we interpret the information these questions can give us differently. An employee's responses to questions about workplace perceptions and job characteristics are a function of the employee's evaluation of his or her work situation. As such, perceptual work data should be considered a property of the individual. They do not become a property of the organization or the collective if they are aggregated to a group or organizational level, despite the fact that this is often done in large-scale surveys. If we want information about work group properties or characteristics, and we want to collect this information by surveying employees, the respondents' frame of reference must be at the collective level. Only then may we aggregate responses across individuals and be justified in interpreting the aggregated data as a group or organizational property (James et al., 1990). For example, a question about the fairness of compensation can be asked at the individual subjective level or the collective level. At the individual level, questions could be (using a standard agree-disagree scale) as follows: "Considering the work I do, I am fairly paid" or "My salary gives me the full amount I deserve." At the collective level, questions would concern the norms that govern the distribution of rewards, such as "People who perform well are those who receive pay raises in this organization" or "Favoritism rather than merit determines who gets ahead in this organization" (for a similar approach to grouplevel measures, see Johnson et al., 1994).

In models of workplace stress, the psychosocial work environment is comprised of variables from the individual, work group, and organizational level. To match the conceptual analyses, research on both the psychosocial work environment and job stress should use multilevel models (see Bliese \& Jex, 2002). Karasek and Theorell (1990) recognized that the psychosocial work environment is a group, or organization, level variable-a property of the context in which the individual works. To deal with data on multiple levels, one needs statistical procedures that take into account the nested structure (the nonindependency) among variables within a hierarchical system. These procedures avoid the traditional problems associated with aggregation, such as the loss of valuable within-group variance or potential problems associated with drawing crosslevel inferences (Bliese, 2000; Bliese \& Jex, 2002; Diez-Roux, 1998). These analyses may be based on individual-level oriented questionnaires (see, e.g., Hammer et al., 2004).

Our second point about measurement concerns data sources. Most work environment surveys collect data from employees only. This makes sense when we are interested in assessing workers' perceptions, attitudes, beliefs, and experiences. These data can only come from the individual because they reflect the significance of work environment characteristics to the individual employee. The assessment of the collective experiences in work groups, however, would be improved by having complementary data from both employees and the employer (or management), because this can provide a perspective on existing norms and values from different vantage points. Management's descriptions of the collective experiences can either confirm the view of the workforce, thereby strengthening the validity of the data, or show discrepancies that by themselves provide meaningful information about the quality of the work environment. Differences in opinions and perceptions of reality between the workforce and its management may indicate latent or hidden problems in the workplace, or attitudes and behaviors among the parties that have consequences for organizational effectiveness and the quality of working life. Warren et al. (1999) found, for example, that the discrepancy between the 
employer's and employees' assessment of risk was an important predictor of stressor levels in the workplace.

It is the psychosocial dimension that in our view will require the development of new instruments. There are validated scales available that measure some of the individual perception components of the psychosocial work environment. The QPS-Nordic (Lindström et al., 1997) or the more recent Copenhagen Psychosocial Questionnaire (2010) could be useful alternatives to the more limited traditional instruments used in earlier studies. To our knowledge, however, there are no existing measures of collective experiences that tap the norms, community, and solidarity dimensions, which means that effort should be devoted to scale construction and validation of these facets.

\section{Conclusion}

In this paper, we have argued that further research progress on the psychosocial work environment has to incorporate collective control: the combination of workplace norms and informal social processes that operate in the workplace and shape employees' expectations about work. The conceptual core of the psychosocial work environment consists of the social interactions (or relations) in the workplace and the work group collective in which these interactions are embedded. This falls well within the Nordic perspective of work environment (Sørensen et al., 2012). We have emphasized that both new and existing measures of the psychosocial work environment have to be organized in two categories, individual perceptions and collective experiences. The development and validation of new instruments and analytical techniques must precede the use of our measurement model.

\section{References}

Agervold, M. (1991). Det gode arbejde i psykosocialt perspektiv. [The good work in a psychosocial perspective.] Nordisk Psykologi, 43, 249-273.

Argyris, C., \& Schön, D. (1996). Organizational learning II: Theory, method, and practice. Reading, MA: Addison-Wesley.

Aronson, G. (1989). Dimensions of control as related to work organization, stress, and health. International Journal of Health Services, 19, 459-468.

Baron, R. S., Kerr, N. L., \& Miller, N. (1992). Group process, group decision, group action. Buckingham: Open University Press.

Berger, P. L., \& Luckmann, T. (1966). The social construction of reality. New York, NY: Doubleday.

Blauner, R. (1964). Alienation and freedom. Chicago, IL: University of Chicago Press.

Bliese, P. D. (2000). Within-group agreement, non-independence, and reliability: Implications for data aggregation and analysis. In K. J. Klein \& S. W. Kozlowski (Eds.), Multilevel theory, research, and methods in organizations (pp. 349-381). San Francisco, CA: Jossey-Bass.

Bliese, P. D., \& Britt, T. W. (2001). Social support, group consensus and stressor-strain relationships: Social context matters. Journal of Organizational Behavior, 22, 425-436.

Bliese, P. D., \& Castro, C. A. (2000). Role clarity, work overload and organizational support: Multilevel evidence of the importance of support. Work and Stress, 14, 65-73. 
Bliese, P. D., \& Jex, S. M. (2002). Incorporating a multilevel perspective into occupational stress research: Theoretical, methodological, and practical implications. Journal of Occupational Health Psychology, 7, 265-276.

Blumer, H. (1969). Symbolic interactionism. Perspective and method. Berkeley, CA: University of California Press.

Brewer, M. B., \& Chen, Y. R. (2007). Where (who) are collectives in collectivism? Toward conceptual clarification of individualism and collectivism. Psychological Review, 114, $133-151$.

Cooper, C. L., \& Payne, R. (1992). International perspectives on research into work, well-being, and stress management. In J. C. Quick, L. R. Murphy, \& J. J. Hurrell (Eds.), Stress and well-being at work (pp. 348-368). Washington, DC: American Psychological Association.

De Jonge, J. J., \& Kompier, M. (1997). A critical examination of the Demand-ControlSupport model from a work psychological perspective. International Journal of Stress Management, 4, 235-258.

De Jonge, J. J., van Breukelen, G. J. P., Landeweerd, J. A., \& Nijhuis, F. J. N. (1999). Comparing group and individual level assessments of job characteristics in testing the job demand control model: A multilevel approach. Human Relations, 52, 95-122.

Diez-Roux, A. V. (1998). Bringing context back into epidemiology: Variables and fallacies in multilevel analysis. American Journal of Public Health, 88, 216-223.

Dollard, M. F., \& Karasek, R. A. (2010). Building psychosocial safety climate. Evaluation of a socially coordinated PAR risk management stress prevention study. In J. Houdmont \& S. Leka (Eds.), Contemporary occupational health psychology: Global perspectives on research and practice, Volume 1 (pp. 208-230), Chichester, Wiley Blackwell.

Dyer, W. G. (1986). Cultural change in small firms. San Francisco, CA: Jossey-Bass.

Edwards, R. (1979). Contested terrain. The transformation of the workplace in the twentieth century. New York, NY: Basic Books.

Emery, F. E., \& Thorsrud, E. (1976). Democracy at work. Leiden, Martinus Nijhoff Publishers.

European Foundation. (1997). Working conditions in the European Union. Second European survey on working conditions. EURF, Dublin, Ireland.

Frese, M. (1989). Theoretical models of control and health. In S. L. Sauther, J. J. Hurrell, Jr., \& C. L. Cooper (Eds.), Job Control and Worker Health (pp. 107-128). Chichester: Wiley.

Ganster, D. C. (1989). Worker control and well-being: A review of research in the workplace. In S. L. Sauther, J. J. Hurrell, Jr., \& C. L. Cooper (Eds.), Job Control and Worker Health (pp. 3-23). Chichester: Wiley.

Gardell, B. (1971). Alienation and metal health in the modern industrial environment. In L. Levi (Ed.), Society, stress and disease. Vol. 1: The psychosocial environment and psychosomatic diseases (pp. 148-180). London: Oxford University Press.

Gardell, B. (1977). Autonomy and participation at work. Human Relations, 30, 515-533.

Gardell, B. (1982). Worker participation and autonomy: A multilevel approach to democracy at the workplace. International Journal of Health Services, 12, 527-558.

Hammer, T. H., Landau, J., \& Stern, R. N. (1981). Absenteeism when workers have a voice: The case of employee ownership. Journal of Applied Psychology, 66, 561-573.

Hammer, T. H., Currall, S. C., \& Stern, R. N. (1991). Worker representation on boards of directors: A study of competing roles. Industrial and Labor Relations Review, 44, 661-680.

Hammer, T. H., Bayazit, M., \& Wazeter, D. (2009). Union leadership and member attitudes: A multi-level analysis. Journal of Applied Psychology, 94, 392-410. 
Hammer, T. H., Saksvik, P. Ø., Nytro, K., Torvatn, H., \& Bayazit, M. (2004). Expanding the psychosocial work environment: Workplace norms and work-family conflict as correlates of stress and health. Journal of Occupational Health Psychology, 9, 83-97.

Hasle, P., \& Møller, N. (2007). From conflict to shared development: Social capital in a Tayloristic environment. Economic and Industrial Democracy, 3, 401-429.

Heckster, C. C. (1996). The new unionism. Employee involvement in the changing corporation. Ithaca, NY: ILR Press.

House, J. S. (1981). Work, stress and social support. Reading, MA: Addison Wesley.

Ilies, R., Dimotakis, N., \& De Pater, I. (2010). Psychological and physiological reactions to high workloads: Implications for well-being. Personnel Psychology, 2, 407-436.

Israel, B. A., Schurman, S. J., \& House, J. S. (1989). Action research on occupational stress: Involving workers as researchers. International Journal of Health Services, 19, 135-155.

James, L. A., \& James, L. R. (1989). Integrating work environment perceptions: Explorations into the measurement of meaning. Journal of Applied Psychology, 74, 739-751.

James, L. R., \& McIntyre, M. D. (1996). Perceptions of organizational climate. In K. R. Murphy (Ed.), Individual differences and behavior in organizations (pp. 40-84). San Francisco, CA: Jossey-Bass.

James, L. R., \& Sells, S. B. (1981). Psychological climate: Dimensions and relationships of individual and aggregated work environment perceptions. Organizational Behavior and Human Performance, 23, 201-250.

James, L. R., James, L. A., \& Ashe, D. K. (1990). The meaning of organizations: The role of cognition and values. In B. Schneider (Ed.), Organizational climate and culture (pp. 416-450). San Francisco, CA: Jossey-Bass.

Jex, S. M., \& Bliese, P. D. (1999). Efficacy beliefs as a moderator of the effects of work-related stressors: A multilevel study. Journal of Applied Psychology, 84, 349-361.

Johnson, J. V. (1989). Collective control: Strategies for survival in the workplace. International Journal of Health Services, 19, 469-480.

Johnson, J. V., \& Hall, E. M. (1994). Individual, environmental, and cultural factors in social support and cardiovascular disease. In A. S. Shumaker \& S. M. Czajkowski (Eds.), Social support and cardiovascular disease (pp. 145-166). New York, NY: Plenum Press.

Johnson, J. V., \& Hall, E. M. (1996). Dialectic between conceptual and causal inquiry in psychosocial work environment research. Journal of Occupational Health Psychology, $1,362-374$.

Johnson, J. V., \& Johansson, G. (1991). The psychosocial work environment: Work organization, democratization and health. Amnityville, NY: Baywood Publishing Company.

Johnson, J. V., McNeeley, E., Muntaner, C., \& Schwartz, J. (1994). The collective control survey instrument. Baltimore, MD: Johns Hopkins University.

Jones, F., Bright, J. E. H., Searle, B., \& Cooper, L. (1998). Modelling occupational stress and health: The impact of the demand-control model on academic research and on workplace practice. Stress Medicine, 14, 231-236.

Kahn, W. A. (1992). To be fully there: Psychological presence at work. Human Relations, 45, 321-349.

Karasek, R. A. (1979). Job demands, job decision latitude, and mental strain: Implications for job redesign. Administrative Science Quarterly, 24, 285-308.

Karasek, R. A. (1985). Job Content Questionnaire, Revision 1.1.

Karasek, R. A. (1992). Stress prevention through work reorganization: A summary of 19 international case studies. In V. Di Martino Conditions of Work Digest: Preventing Stress at Work (pp. 23-41). Geneva, Switzerland: International Labor Office.

Karasek, R. A. (1997). Demand/control model: A social, emotional, and physiological approach to stress risk and active behavior development. ILO encyclopedia of occupational health and safety. Geneva: ILO. 
Karasek, R. A. (2008). Low social control and physiological deregulation-The stress disequilibrium theory, towards a new demand-control model. Scandinavian Journal of Work Environment and Health, 6, 117-135.

Karasek, R. A., \& Theorell, T. (1990). Healthy work: stress, productivity and the reconstruction of working life. New York, NY: Basic Books.

Karasek, R. A., Brisson, C., Kawakami, N., Houtman, I., Bongers, P., \& Amick, B. C. (1998). The Job Content Questionnaire (JCQ): An instrument for internationally comparative assessments of psychosocial job characteristics. Journal of Occupational Health Psychology, 3, 322-355.

Kasl, S. V. (1996). The influence of work environment on cardiovascular health: A historical, conceptual, and methodological perspective. Journal of Occupational Health Psychology, 1, 42-56.

Kasl, S. V. (1998). Measuring job stressors and studying the health impact of the work environment: An epidemiologic commentary. Journal of Occupational Health Psychology, 3, 390-401.

Katz, D., \& Kahn, R. L. (1978). The social psychology of organizations, $2^{\text {nd }}$ ed. New York, NY: Wiley.

Kihlstrom, J. F., \& Klein, S. B. (1994). The self as a knowledge structure. In R. S. Wyer, Jr. \& T. K. Srull (Eds.). Handbook of social cognition (2 $2^{\text {nd }}$ ed., pp. 153-208). Hillsdale, NJ: Lawrence Erlbaum Associates.

Kompier, M. (2002). Job design and well-being. In: M. J. Schabracq, J. A. M. Winnubst, \& C. L. Cooper (Eds.) The handbook of work and health psychology (pp. 429-453). Chichester: Wiley

Landsbergis, P. A., \& Vivona-Vaughan, E. (1995). Evaluation of an occupational stress intervention in a public agency. Journal of Organizational Behavior, 16, 29-48.

Landsbergis, P. A., Mikkelsen, A., Saksvik, P. Ø., Jonge, de. J., Houtman, I., Cedillo, L., Nielsen, M., \& Kristensen, T. (2000). Reliability and validity of the Job Content Questionnaire (JCQ) decision latitude scale. Paper presented at the International Congress of Behavioral Medicine, November 16, Brisbane, Australia.

Lawler, E. J., Thye, S. R., \& Yoon, J. (2009). Social commitments in a depersonalized world. New York, NY: Russell Sage Foundation.

Lindström, K., Dallner, M., Elo, A. L., Gamberale, F., Knardal, S., Skogstad, A., \& Ørhede, E. (1997). Review of psychological and social factors at work and suggestions for the General Nordic Questionnaire. Copenhagen, Nordic Council of Ministers, Nord: 15.

Lord, R. G., \& Brown, D. J. (2004). Leadership processes and follower self-identity. Organization and management series. Mahwah, NJ: Lawrence Erlbaum Associates.

Lysgaard, L. (1967). Arbeiderkollektivet. [Workers' Collective] Oslo: Universitetsforlaget.

Markus, H., \& Wurf, E. (1987). The dynamic self-concept: A social psychological perspective. Annual Review of Psychology, 38, 63-78.

Mikkelsen, A., Saksvik, P. Ø., \& Ursin, H. (1998). The impact of learning opportunities and decision authority on occupational health. Work and Stress, 13, 1, 20-31.

Montgomery, D. (1979). Workers' control in America. Cambridge, UK: Cambridge University Press.

Morrison, D., Payne, R. L., \& Wall, T. D. (2003). Is job a viable unit of analysis? A multilevel analysis of demand-control-support models. Journal of Occupational Health Psychology, 8, 209-219.

National Institute of Occupational Safety and Health (NIOSH). (1998). The Generic Job Stress Questionnaire. Washington, DC: US Government Printing Office.

Nieuwenhuijsen, K., Bruinvels, D., \& Frings-Dresen, M. (2010). Psychosocial work environment and stress-related disorders, a systematic review. Occupational Medicine, 60, 277-286. doi:10.1093/occmed/kqq081 
Oksanen, T., Kouvonen A., Kivimäki, M., \& Pentti, J. (2008). Social capital at work as a predictor of employee health: multilevel evidence from work units in Finland. Social Science \& Medicine, 3, 637-649.

Parkes, K. R., \& Sparkes, T. J. (1998). Organisational interventions to reduce work stress. Are they effective? A review of literature. Department of Experimental Psychology, University of Oxford.

Pierce, J. L., \& Newstrom, J. W. (1983). The design of flexible work schedules and employee responses: Relationships and processes. Journal of Occupational Behavior, 4, 247-262.

Rennesund, A. B., \& Saksvik, P. Ø. (2010). Work performance norms and organizational efficacy as cross-level effects on the relationship between individual perceptions of selfefficacy, overcommitment, and work-related stress. European Journal of Work and Organizational Psychology, 1, 1464-1643.

de Rijk, A. E., Le Blanc, P. M., Schaufeli, W. B., \& de Jonge, J. (1998). Active coping and need for control as moderators of the job demand-control model: Effects on burnout. Journal of Occupational and Organizational Psychology, 71, 1-18.

Rothlisberger, F. J., \& Dickson, W. J. (1939). Management and the worker. Cambridge, MA: Harvard University Press.

Rugulies, R., Aust, B., \& Pejtersen, J. H. (2010). Do psychosocial work environment factors measured with scales from the COPSOQ predict register-based sickness absence of 3 weeks or more in Denmark. Scandinavian Journal of Public Health, 3, 8-24.

Schein, E. (2010). Organizational culture and leadership, 4th ed. San Francisco, CA: JosseyBass.

Shumaker, A. S., \& Czajkowski, S. M. (1994). Social support and cardiovascular disease. New York, NY: Plenum Press.

Siegrist, J. (1996). Adverse health effects of high-effort/low-reward conditions. Journal of Occupational Health Psychology, 1, 27-41.

Skogstad, A., \& Einarsen, S. (1996). Perspektiver på begrepet psykososialt arbeidsmiljø: en analyse av en motivasjonspsykologisk og en stressteoretisk modell. [Perspectives on the concept of psychosocial work environment: an analysis of a motivation- and a stress model.] Nordisk Psykologi, 48, 200-213.

Soderfeldt, B., Soderfeldt, M., Jones, K., Ocampo, P., Mountaner, C., Ohlson, C. G., \& Warg, L. E. (1997). Does organization matter? A multilevel analysis of the demand-control model applied to human services. Social Science \& Medicine, 44, 527-534.

Sparks, K., \& Cooper, C. L. (1999). Occupational differences in the work-strain relationship: Towards the use of situation-specific models. Journal of Occupational and Organizational Psychology, 72, 219-229.

Spell, C. S., \& Arnold, T. J. (2007). A multi-level analysis of organizational justice climate, structure, and employee mental health. Journal of Management, 33, 724-751.

Strauss, A. L. (1993). Continual permutations of action. Hawthorne, NY: Aldine De Gruyter.

Sørensen, O. H., Hasle, P., \& Hesselholt, R. R. (2012). Nordiske Perspektiver på Arbejdsmiljø- Mening, Indflydelse og samarbejde [Nordic work environment perspectives meaning, control and cooperation]. NMR-rapport, Det Nationale Forskningscenter for Arbejdsmiljø. Nordisk Ministerråds rapportserie.

Theorell, T., \& Karasek, R. A. (1996). Current issues relating to psychosocial job strain and cardiovascular disease research. Journal of Occupational Health Psychology, 1, 9-26.

Torp, S., Grøgaard, J., Moen, B., \& Bråtveit, M. (2005). The impact of social and organizational factors on workers' use of personal protective equipment: A multilevel approach. Journal of Occupational \& Environmental Medicine, 8, 829-837.

Van der Doef, M., \& Maes, S. (1999). The job demand-control (-support) model and psychological well-being: A review of 20 years of empirical research. Work \& Stress, 13, 87-114. 
Van Yperen, N. W., \& Snijders, A. B. (2000). A multilevel analysis of the demand-control model: Is stress at work determined by factors at the group level or the individual level? Journal of Occupational Health Psychology, 5, 182-190.

Wahlstedt, K. G. I., \& Edling, C. (1997). Organizational changes at a postal sorting terminal-Their effects upon work satisfaction, psychosomatic complaints and sick leave. Work Stress 11, 279-291.

Warren, N., Karasek, R., Punnett, L., \& Houtman, I. (1999). Worker-employer risk estimate disparity: Identifying the unhealthy organization. Paper presented at Work, Stress and Health '99: Organization of Work in a Global Economy (APA, NIOSH), Baltimore, MD.

Winnubst, J. A. M., \& Schabracq, M. J. (1996). Social support, stress and organization: Towards optimal matching. In M. J. Schabracq, J. A. M. Winnubst, \& C. L. Copper (Eds.), Handbook of work and health psychology (pp. 87-102). Chichester: John Wiley.

\section{End notes}

${ }^{1}$ These factors were found to be invariant over a wide variety of work environments. Each one consists of several specific, or second-order, factors.

${ }^{2}$ The definition of a phenomenon as a social construction comes from the school of thought known as symbolic interactionism (e.g., Berger \& Luckmann, 1966; Blumer, 1969; Strauss, 1993). To recognize that the psychosocial work environment is a social construction, however, does not mean that one must accept the central tenet of symbolic interactionism, that all reality is socially constructed. For our purpose, this is not a debate we need to entertain.

${ }^{3}$ Other models of organizational culture describe it as consisting of four levels: artifacts, norms (or perspectives), values, and basic assumptions (e.g., Dyer, 1986). The important point is that norms and basic assumptions are different phenomena-norms may be based on basic assumptions, but they differ both conceptually and operationally. 